\title{
Local identity and self-identity of residents of northern Russian cities of Arkhangelsk and Severodvinsk ${ }^{i}$
}

\author{
Natalia Drannikova ${ }^{1, *}$, and Inga Zashihina ${ }^{2}$ \\ ${ }^{1}$ Northern (Arctic) Federal University named after M.V. Lomonosov, Cultural and Religious Studies Department, 163002 \\ Arkhangelsk, Russia \\ ${ }^{2}$ Northern (Arctic) Federal University named after M.V. Lomonosov, Department of the English Philology, Northern European \\ Languages and Language Pedagogy, 163002 Arkhangelsk, Russia
}

\begin{abstract}
Local population survey based on specially developed questionnaire was held to study local identity of Arkhangelsk and Severodvinsk in the Arkhangelsk region (Russian North) from 2000 till 2015. Aquired folklore and speech data allow us to analyze Arkhangelsk and Severodvinsk citizens' local identity distinctive features. The held research allows one to make a conclusion that the Arkhangelsk and Severodvinsk citizens have their own developed local identity, but with different specific characteristics. The local population has their own images of themselves and other people/neighbours. Arkhangelsk was founded as a traditional town, Severodvinsk - during country urbanization processes. Severodvinsk inhabitants have double or triple identification more often than Arkhangelsk citizens.
\end{abstract}

\section{Introduction}

Identity is a theoretical construct which explains the behaviour of individuals acting as group members as well as their attitudes to the membership in this group. In our globalised world, the question of what it means to belong to a particular group, place or locality acquires more and more significance. Large numbers of people live globally, changing their locations both physically and mentally. Increased mobility rates make people's identities blurred and problematic to understand. However, this is vital for many reasons. Identity is crucial in terms of self-perception, defining individual's life aspirations, self-categorization and citizenship. In the situation of permanent changes of the modern world, an individual is in need for stability and reassurance. One way to satisfy such need is through stronger local identification. Theoretical underpinnings of the latter can be expalined by the significance attributed to place and local culture.

Identity as an object of research is described by numerous theories in different study areas - Psychology, Anthropology, Philosophy, Religious Studies, Education, Cognitive Studies. Poststructuralist view of the subject, prominent for its resonance, is expressed by philosopher Michel Foucault, who asserted that identity is a form of social construction which people impose on themselves and others [1]. Communication scholars accord with this view and suggest that identity is interpersonal and constructed through interaction with others in their community [2]. Identity is shaped through these interactions inside families, culture, gender, ethnicity, class, and geographical groups. Local identity is one of the types of social identity and can be defined as a person's identification with local community, which results in senses of involvement, commonality and belonging to the events happening in the area of a person's residence. Local identity of the residents of two northern Russian cities of Arkhangelsk and Severodvinsk is going to be the subject of this article.

The aim of our research includes 1) the description of local identities of Arkhangelsk and Severodvinsk residents and 2) the comparative analysis of local identities of Arkhangelsk and Severodvinsk residents. For this purpose, a survey of the local population has been conducted during the period of 2000-2015. The subject of study encompassed speech and folklore data. The interviews combined questions ... Respondents' reactions comprised oral and written texts produced as a feedback to the interviewer's questions, both planned and spontaneous. In total, five hundred people aged 1690 were interviewed.

As a research area, local identity has long been out of the perspective of Russian scientists. The obstacle on the way of the study of local identity was the fact that geographical locations were sooner approached as the subject field of science and not humanities. Its research was shielded by the research on ethnic identity. However, tradition and culture, being direct factors of identity formation, are characterised by the features common to specific localities. Therefore, it was only natural to change the frame of research and eventually scientists shifted their attention to local identity.

During the last decade, a range of studies on local identities of regions of Russia has been produced.

* Corresponding author: n.drannikova@narfu.ru 
Russian researchers began to appraise local identity as a type of personal identity, which can generally be identified through the feelings of involvement into the activities happening on the territory of a person's dwelling. Among the authors, we need to point out I.A. Razumova [3], E.V. Golovneva [4], P.L. Krupkin and S.D. Lebedev [5]. Local text studies carried out by V.V. Abashev [6], M.L. Lurje and A.A. Alexeevsky [7] also tightly connected with the research on local identity.

\section{Problem areas of space and place in the context of globalisation}

The notions of space and territory are getting more relevance for study in the context of globalisation. Globalisation makes the traditional view on identity invalid, breaking the assumed isomorphism of space, place, and culture. Numerous studies have attempted to explain the destructive influence of globalisation on cultural identities, for example, J. Lull [8], B. Shepard and R. Hayduk [9], Jan Aart Scholte [10]. Whereas in classical anthropology cultures were mapped onto places and peoples, in the contemporary world characterised by extensive people"s mobility, cultural identity seems to be highly obscure. Greek researcher Paraskevas Potiropoulos [11], analysing the features of local identity in the postindustrial society, argues that identity is growing flexible and hybrid, while the connection with locality is becoming symbolic, though it is still present.

The social and psychological attachment of an individual to locality is a powerful phenomenon of human experience. Manual Castells points out the capacity of identity to step out as an oppositional force to globalisation. In this view, local identities possess the inner ability to challenge the damaging effects of globalisation and to state its own powers. To illustrate this feature of identity Castells provides the cases of local consumption preferences and examples of cultural identity movements [12, pp. 146-166]. The researcher declares that local identity is «people's source of meaning and experience».

However, local identity is a complex phenomenon, forming its nature in the context of modern capitalist culture and operating simultaneously and interrelatedly in the economic, technological-communicational, political and cultural spheres of human life. It is not enough though to determine human experience in terms of lifestyle only. The entangled contemporary conditions of human existence, which influence local identities, were described in Giddens's theory of modernity [13]. The whole range of institutional features identifies the idea of cultural modernity, meaning the abstraction of social and cultural practices from contexts of local particularity, and their institutionalization and regulation across time and space [13].

Researchers on local identity observe that in the conditions of globalisation regional identitites come as a means of objectification and construction of difference within sociocultural practices. British scientist J.G. Prendergrast highlights that locality is a necessity for social existence in asmuch as it is almost impossible to distinguish «who we are» from «where we are from» [14]. Gupta and Ferguson argue that deterritorialisation, caused by globalisation, destabilized the fixity of «ourselves» and «others» [15]. Generally, the diminishing significance of socialgeographical location to the mundane flow of cultural experience is noted. It is not locality as a spacial structure that counts in the process of identity formation, but the agency of constructing our daily lives in the existing context of modernity.

The social study of Bourdieu [16] provides theoretical framework within which the interplay of structure and agency through social space positions and internalized value systems of individuals can be conceptualised. We find Bourdieu's interconnected concepts of field and habitus, helpful to understand the construction of local identity of the residents of Arkhangelsk and Severodvinsk, two northern Russian cities. The population of these geographic localities, alongside with the physical spacial settings, comprise a social field with its own sets of rules, resources, and stakes [16]. Habitus describes those internalised structures, dispositions, tendencies, habits, ways of acting that are both individualistic and yet typical of one's social groups, communities, family, and historical position. Habitus of Arkhangelsk and Severodvinsk citizens' includes their folklore and speech practices, coming as resources to develop new meanings, connections, associations, topologies and other manifestations of their identitites. In this paper, we are aiming at research on consequential features, which are commonly acknowledged by the respondents and bibliographical sources to describe the local identity of Arkhangelsk and Severodvinsk residents. To distinguish the essential characteristics, meaningful in terms of local identity, we are following E.V. Morozova and E.V. Ulko, who point out the following:

- identification with the motherland

- identification with the landscape and climatic conditions

- identification with historical and cultural events

- identification with local famous people

- identification with the economic activities of the area

- identification with the level of socio-economic development

- identification with specific, real or imagined, features of public behaviour [17].

\section{The cities of Arkhangelsk and Severodvinsk}

The cities of Arkhangelsk and Severodvinsk are situated nearby, the distance dividing them is not bigger than 50 $\mathrm{km}$, but their history is very different. Arkhangelsk is an old city, arousing historical and ethnic associations, whereas Severodvinsk is a Soviet industrial town. Arkhangelsk was built in 1584 as a fortress city, the mission of which was the development of international trade and defence of northern Russian borders. The first inhabitants of Arkhangelsk were the families from the neighbouring villages moved there by the government 
[18]. During the whole history of the city, the majority of its residents were locals. The structure of the population changed after the World War I and even more after the Civil War, when people living in Arkhangelsk, Vologodskaya and other provinces streamed to Arkhangelsk in order to work at timber mills [19]. During the period of industrialisation, starting from the middle of 1920-ies, old timber mills were renovated and new plants were built [20]. This was the time when Arkhangelsk acquired its status of «the country's currency workshop» in the official state discourse $[19, \mathrm{p}$. 42]. To promote the development of forest industry, special recruitments were held and migrants from central regions of Russia as well as the convicted were directed to the city [20]. Nonetheless, the main share of the city"s population were people coming from various parts of Arkhangelsk region.

The processes taking place in the country have influenced the cultural appearance of the city of Arkhangelsk to a large extent. Politburo of the Central Committee of the Communist Party adopted the resolution "On measures for the elimination of kulak households in districts of comprehensive collectivization" on 30 January 1930. As a result of the dekulakization operation, more than 300,000 people were exiled to the Northern Krai. The number of special settlers in Arkhangelsk sharply increased in the early 1930's. By the early 1932, special settlers, administratively-expelled and other "class aliens" were working at factories and constructions of Arkhangelsk and its environs. This led to a stronger opposition between the city center and its outskirts in the minds of citizens and the marginalization of environs.

Severodvinsk was built as a new industrial and socailist town. Its history goes back to 1936, when the settlement of Sudostroy was founded. Its territory was used for the construction of a shipbuilding factory [19, 21]. In 1930-ies the majority of Severodvinsk's population were the prisoners of GULAG (Soviet concentration camps), who were sent there exactly with the purpose of the factory building (22, pp. 228-255, 23, pp. 216-244). The rest of the inhabitants came from Arkhangelsk region and neighbouring provinces [19, p. 364]. The fact that the town was built with the labour of prisoners and forced migration was concealed during the Soviet period and officially the founders of the city are considered to be 60 people who came to the location on board a wheel ship named after Ivan Kalyamin. In 1988, a monument was fixed at the place of their disembarkment along the road to Yagry island. The regional ethnographer Shmigelsky wrote: «The construction included thousands of people, predominantly residents of Arkhangelsk, Vologodskaya, Northern Dvinskaya and Komi regions, which at that time were a part of the Northern land. Most of them had previously been engaged in farming and had just a vague understanding of what industrial shipbuilding was...» [24, p. 99]. In official record, the construction of Severodvinsk was compared with the construction projects of the first five-year plans - Komsomolsk-onAmur, Turksib, Magnitka. In the 1950-ies, shipbuilding factories became multiple and started deriving the population from the villages of Arkhangelsk and Vologodskaya regions. The appearance of Severodvinsk was very similar to the formation of the towns of the Kolsk North, which were also built as industrial centres during the Soviet period [25].

\section{Self-nominations}

The most vivid evidence of local identity is selfnomination of the local community. Arkhangelsk residents call themselves «treskoedy», cod eaters. They also speak of their city as the place of wooden bord, the place of boredom, the gate to the Arctic. The names derive from the stereotypes on food biases and behaviour patterns of the local community, as well as its professional occupations. For example, cod species of fish are very common in the local waters and available as food the whole year round here. The main jobs are found in forest industry. Northerners are often considered gloomy and cheerless. There is a large number of selfreferential sayings, proverbs and riddles which are connected with self-nominations and explain them. Modern citizens of Arkhagelsk use the descriptive nominations for the city, which go back to the Soviet rhetoric. They believe their city to be famous as the gates to the Arctic, country's sawmill and the city of fishermen. Arkhangelsk used to be the starting point of all the Arctic expeditions, hundreds of ships began their way along the Northern Sea Route here [19, p. 42].

Krupkin P.L. claims that local community's conception of local geography makes the nucleus of the collective identity [26]. According to Zamyatin D.N., local geography includes «stable representations of space, which are formed in various areas of culture as a result of some human activity (at both domestic and professional levels)» [27, p. 92]. The nomination country's sawmill appeared in 1920-ies, when many new timber plants were built $[19$, p. 42]. The characteristic of Arkhangelsk as a city of fishermen roots in professional occupation of its residents. Fish has long been the main source of trade of Arkhangelsk with other Russian regions and Western countries. Lately one more name for the city appeared - tupik (dead end). Its is especially spread among the youth and reflects those facts that the Northern railway finishes in Arkhangelsk, that White Sea is situated as far as $50 \mathrm{~km}$ away from the city and also that Arkhangelsk cannot enjoy as high level of life, socio-economic and cultural facilities as the capitals of the country.

At the same time, Severodvinsk residents call themselves shipbuilders, whereas the town receives the title of the town of shipbuilders. Both cases of selfnominalisation refer to the narrative stereotypes of the Soviet discourse. In the town, there are two big shipbuilding factories where atomic powered submarines are made. This explains the semantic origin of another self-nominalisation of Severodvinsk - underwater atom [28, p. 343]. In contrast to the local identity of Arkhangesk residents, the local identity of Severodvinsk residents is tightly connected with their professional identity. 


\section{Local mythology}

Among those factors that support and strengthen local identity are famous or outstanding fellow countrymen's, favourite local routes, symbolic sights. Cultural value component plays a crucial role in the structure of local identity, local mythology being its vital constituent. Collective memory creates the images of place and local community. It includes reflexivity on the city's name. The main aetyologic plot of oral city prose is the story of how the place received its name. Arkhangelsk residents ascribe the name of the city with a sacral meaning. The city obtained its name after Mikhailo-Arkhangelsk monastery, which used to occupy the territory of the future city. The legend tells that tsar Peter the Great $(1672-1725)$ took part in giving the city its name. Peter the Great had a dream, in which archangel Michael arrived in front of him and spoke of the necessity to build a new port city. Even if the construction of the city occured earlier, during the reign of Ivan the Terrible (1530-1584), in Arkhangelsk ethno-cultural tradition the image of Peter the Great has a sacred significant position [28, pp. 228-229]. There exists a large number of oral stories, where Peter the Great is given the credit of a name-giver for various settlements of Arkhangelsk region. Local people claim that sacred forces did not allow the city to be renamed when in 1929 , there was an attempt to change the name for Stalinoport.

The majoroty of Severodvinsk's residents are able to give the town's previous names — Molotovsk and Sudostroj. All of our respondents are aware of the name's origin, since the town is situated in the mouth of the Northern Dvina river (Severnaya Dvina), and this is where the name derives from. According to our findings, the central aetiologic plot of Severodvinsk's history is the legend on the origin of Yagry island's name. Nowadays the island is a part of Severodvinsk town, whereas in 1553 this was the spot of mooring the ship of an English expedition organised to search for a way to China and India through Arctic. The ship happened to be the only one left in the course of the trip under the command of captain Richard Chancellor. The island was covered with blossoming rosehips and looked pink, that is why the Englishmen called it a Rosy Island, and with this name the island is denoted on foreign maps of the seventeenth c. 29, pp. 131-133]. Later local people traced the origin of the finno-ugric word Yagry to the English language, Richard Chancellor himself became a cultural hero of Severodvinsk folklore.

Historical and cultural collective memory of Arkhangelsk residents is primarily framed within the second half of the twentieth century. This is expalained by the contemporary migration situation and the structure of the respondents' corpus. However, we have a record of tales about wonders, which happened in Arkhangelsk churches in the XIX - XX century, about Arkhangelsk of war times and also about the residents punished for dishonourable treatment of objects of worship. Our respondents give the construction of a shipyard in 1693 among meaningful events in Arkhangelsk's fate [30]. In 1922, the shipyard was transformed into the shipbuilding plant «Krasnaya
Kuznitsa». Other symbolic milestones were the activity of the first Russian seaport in Arkhangelsk, foundation of Novodvinsk Fortress in 1701 (the period of the Northern war) [18], demolishion of Troitsky cathedral church (1928 - 1931) and international sea convoys to Arkhangelsk, which were held during World War II.

Historical and cultural memories of the residents of industrial town Severodvinsk include the events of the Soviet period. These are such episodes as the repairments of the atomic icebreaker «Lenin» at the shiprepairing plant «Zvesdochka» (1967- 1970), which later brought Severodvinsk the order of Lenin (1983). Only a few Severodvinsk residents know the historical fact of the town's foundation at the place of the former Nikolo-Korelsky monastery. The monastery can be traced to 1419 and is noted as the place where the sons of Marfa Borteskaya (an important Great Novgorod figure) were buried in 1471 [31, pp. 44-47]. There are also a few respondents who have read about the arrival of English traveller Richard Chancellor to the bay Dvinskoy. Ancient historical data were received by them via regional literary ethnographic publications.

Historical events kept in memory of Arkhangelsk and Severodvinsk residents represent «contratext», which interprets and transforms certain images and episodes in accordance with folk tradition. The undertaken investigation proves that there is a collective memory of the communities of Arkhangelsk and Severodvinsk representatives. At the same time, it has shown that Severodvinsk residents primarily keep in mind those circumstances which refer to the industrial Soviet past of the place.

\section{Arkhangelsk and Severodvinsk residents perceived by other regions of Russia}

Symbolic image of a city is connected with the way it is perceived by non-residents. Comparisons are made during specific communicative situations, when nonresidents meet citizens of Arkhangelsk and Severodvinsk. They ask, for example, whether there are deer in Arkhangelsk. In the South, it is supposed that white bears and penguins walk along Arkhangelsk streets. Older generation representatives recall episodes when they were asked if local population, the Nenets, really rode deer across the city or if cod cost five kopecks (pennies ${ }^{\mathrm{ii}}$ ). Nenets autonomous district is a part of Arkhangelsk region, whereas cod used to be very cheap in the USSR. Arkhangelsk and Severodvinsk are associated with cold climatic conditions and white nights, that is why one of the traditional inquiries to be made by the southerners sounds like: «Is it true that one can read books without electric light even at nights at

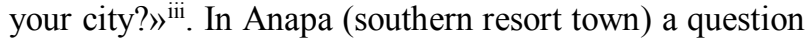
was asked «How many wigwams are there in the city?» (chums were meant). People were also interested to know whether we freeze when temperature goes above fifty degree. Both Arkhangelsk and Severodvinsk residents are questioned about facts connected with their jobs and geographical positions of the cities they live in. For example, if there are many sailors in Arkhangelsk? 
Severodvinsk residents are asked whether they swim in the sea near submarines. Those who possess a sense of humour, reply positively. Others explain that there are no bears and it is as cold as in Saint Petersburg. Folklorization of this dialoque situation is very common for the culture of northern cities.

Oral interviews reveal a number of key words characteristic of Arkhangelsk and its residents - white bear, ice, deer, reindeer team, permafrost. Arkhangelsk and Severodvinsk residents are often called frozen, frostbitten, frozen down; their temperament features and behaviour patterns being pointed out in this fashion. These exonyms encompass ethnopasychologic stereotypes of Arkhangelsk and Severodvinsk residents as observed by other territorial communities. Key symbols of the location - white bears, ice, deer, permafrost and metaphoric epithets frozen, frostbitten, frozen down - are natural for the regions with cold climate as well as their inhabitants.

There exist nearly identical stereotypes of how Arkhangelsk and Severodvinsk residents are perceived by non-residents. They are related to the ideas on geographical position (seashore) and arctic climate of these cities. Attitude to the residents of Severodvinsk is also defined by their professional activity.

\section{Stereotypic representations of each other}

Feasable correlations between groups, which make it possible to compare resident and non-resident communities, are also an important feature of indentity. When one group of individuals assesses itself as related to outsiders, criteria of identity become prominent. In folklore speech practice of Arkhangelsk and Severodvinsk residents, their own stereotypic representations are realised. Northerners juxtoppose their character and behaviour features to the southerners. They believe inhabitants of the North to be kinder, calmer, tidier, more honest, hospitable, sincere, intelligent and hard working as compared to the inhabitants of the South. Feeling of belonging to the North, but not to some definite city is important in the opposition between southerners/northerners. This sense of opposition is common for all citizents of Arkhangelsk North. Analysing themselves in relation to the southerners, northerners ascribe to themselves positive features only. Ethnocentrism is indicative of Arkhangelsk residents, as well as many other local communities. They consider themselves to be respected by everyone; sailors from different cities would be glad to talk to those coming from Arkhangelsk. The presence of such stories provides one more way of self-identification with the city.

Respondents accept various constitutive features of the community as their own and identify themselves with the community. The image of a typical Arkhangelsk resident coincides with the portrait of all the northerners. According to the respondents such traits of character as honesty, reserve, firmness, endurance, freedom of spirit, dignity, kindness and restraint are general for an Arkhangelsk dweller. While they define their own features of character, Arkhangelsk respondents manifest the tradition of a pomor description, as formed in local lore, science and fiction literature [32]. Pomors are a minor ethnographic community of old timer population of the White Sea shore, whose main occupation were marine fisheries [19].

According to our respondents, the typical features of Severodvinsk dwellers are diligence, hospitality, friendliness, and physical endurance. Many of the respondents noted that indifference, apathy, or calmness, lack of initiative are also very common for these people. Town residents find themselves introvert. Speaking about an average Severdvinsk dweller, informants often adress him/her as a fabric worker, a plodder, thus pointing out the value of industrial enterprise in town's life and the monotony of people's activities.

Self-identification of Arkhangelsk and Severodvinsk citizens contains many common points. However, autostereotypes of Arkhangelsk city dwellers have undergone serious influence of literature tradition in pomor description.

Relationship between Arkhangelsk and Severodvinsk residents and those features, which they ascribe to each other, have presented interest for this investigation. Arkhangelsk city dwellers of older generation, who remember Severodvinsk being a military town with restricted access, think it to be better educated and even elite, since the town's professional specialisation makes it more important for the state. They also find this the reason for the town to be luckier in terms of alcoholism, criminal and parasitism rates; occupational profile has brough up the sense of responsibility in people. The town itself is considered to be cleaner and more comfortable, than Arkhangelsk. At the same time it is regarded as provinsial compared to Arkhangelsk, but this feature give Severodvinsk dwellers an advantage - they are spoken of as more sincere and kindherated, than Arkhangelsk city residents. We have even encountered the case of using a citation from Bernard Show's to compare the cities of Arkhangelsk and Severodvinsk: «The bigger the city, the lonelier the person feels» (interview with Zorin V.I., born in 1957, Arkhangelsk). The respondent meant that Severodvinsk is a provincial city and it is more comfortable for a man's spiritual life. Severodvinsk residents, speaking about their difference from Arkhangelsk city dwellers, give themselves and their town more favourable characteristics. They think themselves more intellegent, kind-hearted and easygoing. They even find the streets of the town tidier, than in Arkhangelsk. Difference in the infrastructure and speed of life of the two cities is also noticed.

\section{Symbolic imagery}

Arkhangelsk and Severodvinsk are known for their symbolic imagery. The majority of Arkhangelsk symbols belong to cultural life and topography. There are also industrial symbols valued by the city dwellers. Among Arkhangelsk cultural icons, our respondents mention Wooden Arts Museum «Malyje Korely», State Academic Russian Northern Folk Choir, fairy tales by S.G. Pisakhov (1879 - 1960). Arkhangelsk writer, 
wooden pavements, which are still preserved on some city streets and wooden houses. Arkhangelsk is presented as a wooden city of the sixteenth century or a city with wooden architecture, covered with snow, with no reference to the historical period. Several respondents have also memorized the cases of mass execution that took place near Arkhangelsk in 1920 - 1930, and refered them to symbolic events of the city. Illustrative imagery is influences by pictures to the books of fairy tales by S.G. Pisakhov, famous writer. One more Arkhangelsk symbol, offered by the informants, is the fragrance of spring trees. City residents of older generation, who know works of local writers well, recognise that the image of Arlkhangelsk has been formed on the basis of their creations.

Symbolic imagery of Severodvinsk can be divided into five groups - natural and landscape, cultural and topographical, industrial, musical and cultural (literature and cinematic). Our respondents noted that their Severodvinsk is a frozen and covered with snow shore of the White Sea, sometimes - the White Sea by itself, dunes, ice blocks in the raging ocean, fir trees, covered with fluffy snow, swamp. Industrial images encompass the shipbuilding factory, submarines, the sea with a submarine, coming out of its depth. There is also one more group, close to the industrial one, which includes landmarks connected with professional activities of the local community. These are the monument to the former head of the shipbuilding factory G.L. Prosyankin, made in the form of a bolt, and two steles. One of the steles is set to honour the town builders and the other, with the town emblem is installed in the honour of Severodvinsk town, which was founded at the place of the settlement named Sudostroj on 1938. Musical imagery includes the sound of the surf, the cries of seagulls, Severodvinsk enthem. The group of cultural symbols holds musical and poetical film «From the Height of Bird Flight», issued in 2006. In this film, Severodvinsk is shown as a centre of atomic shipbuilding. Compared to Arkhangelsk symbols, Severodvinsk imagery contains mostly lanscape and industrial symbols, whereas cultural icons are united with manufacturing items (industrial group).

\section{Famous people}

Local identity is revealed through the presence of famous people, whom local community identifies with. Arkhangelsk residents primarily give names of those personalities, who have greatly contributes to the history, culture and science of the city. To such figures, they refer K.P. Gemp, a researcher of pomor culture, S.G. Pisakhov, a writer of fairy tales, E.S. Kokovin. children's novelist, J.A. Barashkov, a researcher of old Arkhangelsk architecture, V.N. Burchevsky, the head of th Folk Arts School, A.L. Nevzorov, the former rector of Arkhangelsk State Technical University, V.P. Panov, the head of the Youth Theatre, the former mayor A.V. Donskoj, the local eccentric Drevarkh, the scandolously known journalist I. Azovsky, a tycoon V.Y. Krupchak. In any period of city life, its mayor is considered a notable person.
As for Severodvinsk famous people, they are not so numerous, according to the local community. This circle encloses the former factory heads G.L. Prosyankin, N.Y. Kalistratov, D.G. Pashaev and the present mayor M.A. Gmyrin. Thus, Arkhangelsk well-known people are mostly figures of culture and science, while Severodvinsk remarkable citizens come from industry and management.

\section{Conclusion}

To summarise, it is necessary to mention that local identity of Arkhangelsk and Severodvinsk residents is tightly connected with historical processes. Arkhangelsk history is longer than 4 centuries. Historically and culturally it was regarded as a central city of Russian North, the core of traditional culture. Severodvinsk is opposed as an industrial town. Severodvinsk dwellers local identity demonstrates values of the modern society, values of civilisation, but not of culture. The presence of self-nominations of Arkhangelsk and Severodvinsk residents proves a developed local self-consciousness. They recognise themselves independent local communities. Ethnopsychologically speaking, residents of both cities find themselves calm, balanced, able of overcoming difficulties. They also juxtoppose themselves to the population of Central Russia. Besides local identity of the majority of Severodvinsk citizens coincides with their occupational identity.

We claim that Arkhangelsk possesses a conceptual cultural dominant - it is a northern city-port, the starting point of all the Arctic expeditions, its residents are endowed with pomor self-consciousness. The fact that its symbols comprise Arts Museum «Malyje Korely» and State Academic Russian Northern Folk Choir partly proves that Arkhangelsk city dwellers emphasize their continuity as the bearers of peasant culture of Russian North. Severodvinsk conceptual dominant represents a factory town standing on the White sea, where submarines are built. Symbolic images of Arkhangelsk and Severodvinsk coincide in terms of topography. Informants note the usual for cities spaces, sea and snowy winters. Besides there is a partial imagery coincidence at the level of professional life. For the residents of older generation Arkhangelsk is a city of shipbuilders and sailors; Severodvinsk is a shipbuilding centre for the residents of all ages.

The undertaken analysis shows that Arkhangelsk and Severodvinsk residents have both positive and negative local identities. Respondents with positive identity possess a deeper historical memory. They know their city's past well, have favourite sights and routes, are fond of the local natural landscape. They are also proud of the city of their residence and see the perspectives for its development. Residents with negative and neutral identities do not possess historical memory. They know little about the city's history and its celebrities; they poorly navigate in the city's present and are ready to move whenever they have the opportunity.

The fascinating history and ages-long development of the city as one of the cultural and political centres of 
Russia are determining for the local self-identity. Arkhangelsk has long been a capital of the Russian North, that is why its dwellers have a better developed regional self-identity, than Severodvinsk citizens. Along a strong Arkhangelsk residents' identity, dwellers of the city often possess additional local identities, which are connected with the fact that the place is a historical motherland of their ancestors. This role is usually carried out by one of the settlements in Arkhangelsk region. Arkhangelsk population has grown out of its rural neighbourhood.

Severodvinsk citizens often have different basis for their self-identity. Severodvinsk is a town-enclave, which is partly determined by its geographical position on the shore of the White Sea, but mainly by the professional occupations of the town dwellers. That is why Severodvinsk dwellers, like Arkhangelsk citizens, have patriotic feeling towards their place of residence. Patriotism is tightly connected with the state contemporary policies. Atomic shipbuilding belongs to the military sector, favoured by the modern politicians, and state propaganda emphasises its value. Economically speaking, this industry has large potential for development. Local identity is impacted by these factors, and there is reason to suggest that local identity is bound to change in synchrony with the state policies of Russian Federation.

\section{References}

1. M. Foucault, The Birth of the Clinic: The Archaeology of Medical Perception (Routledge, London, 2003)

2. Cross-Cultural Interpersonal Communication (International and Intercultural Communication Annual) (Sage Publications, Newbury Park, 1991)

3. I.A. Razumova, Nations and cultures adaptation to the environmental, social and technology-related changes (ROSSPEN, Moscow, 2010)

4. E.V. Golovneva, Ural Historical Journal 2, 81-88 (2013)

5. P.L. Krupkin, S.D. Lebedev, Sociological Journal 4, 35-48 (2013)

6. V.V. Abashev, Perm as text. Perm in Russian culture of XX century (PSU Publ., Perm, 2000) (in Russian).

7. M.D. Alekseevsky, A.M. Zherdeva, M.L. Lurje, A.A. Senkina, Forum for Anthropology and Culture 8, 419-422 (2008)

8. J. Lull, Media, Communication, Culture: A Global Approach (Polity, Cambridge, 2000)

9. From ACT UP to the WTO: Urban Protest and Community Building in The Era of Globalization (Verso, London, 2002)

10. J.A. Scholte, Globalization: A Critical Introduction (Palgrave Macmillan, Basingstoke, 2005)

11. P. Potiropoulus, Proceedings of the 15th Congress of the I.S.F.N.R. (Athens, 2014)

12. M. Castells, The Power of Identity (Wiley, Blackwell, United Kingdom, 2010)

13. A. Giddens, The Consequences of Modernity (Stanford University Press, Stanford CA, 1990)
14. J. Prendergast, Regional Identity and Territorial Integrity in contemporary Russia. A New Russian Heartland?, URL: http://www.le.ac.uk/geography/research/RussianHear tland/index.html (date of access: 15.04.13)

15. A. Gupta, J. Ferguson, Cultural Anthropology 7 (1), 6-23 (1992)

16. P. Bourdieu, The Logic of Practice (Stanford University Press, Stanford CA, 1990)

17. E.V. Morozova, E.V. Ulko, Politeks 4, 139-151 (2008)

18. V.V. Krestinin, Brief history of the City of Arkhangelsk (IAS, St. Petersburg, 1792)

19. A.A. Kuratov, Pomor Encyclopedia (PSU Publ., Arkhangelsk, 2001)

20. S.I. Shubin, Northern Krai in the history of Russia. Problems of regional and national politics (PSU Publ., Arkhangelsk, 2000)

21. L.G. Shmigelskyy, History of Severodvinsk and Sevmash (Severodvinsk Press, Severodvinsk, 2013)

22. S.K. Bondarevsky, Severodvinsk. Test for durability. Essays, memories, studies, (Truth of the North, Severodvinsk, 1998)

23. T.F. Melnik, "Yagry Corrective Labour Camp in Molotovsk" in Hard labour and exile at the Russian North (Kira, Arkhangelsk, 2006) (in Russian).

24. L.G. Shmigelskyy, Severodvinsk. Test for durability. Essays, memories, studies, edit. A.A. Maslennikov (Truth of the North, Severodvinsk 1998)

25. I.A. Razumova, Cultural landscapes of the Kola North. Social and anthropological essays (Gamas, St. Petersburg, 2009)

26. P.L. Krupkin, Public management: theory and practice 3-4, 303-311 (2010)

27. D.N. Zamyatin, Culture and space: modelling of geographical images (Sign, Moscow, 2006)

28. N.V. Drannikova, The Local-Group Nicknames in Traditional Culture of the Russian North. Functionality, Genre. System, Ethnopoetics (PSU Publ., Arkhangelsk, 2004)

29. N.V. Kabinina, Substrat toponymy of Arkhangelsk Pomorye (Ural University Publ., Ekaterinburg, 2011)

30. S.F. Ogorodnikov, Essay on history of the city of Arkhangelsk in industrial interpretation (Admiralty Press, St. Petersburg, 1890)

31. P.P. Soykin, "Nikolo-Korelsky Orthodox Christian Russian shrines: Complete illustrated description of Orthodox Christian Russian monasteries in the Russian Empire at the Athos, (Resurrection, St. Petersburg, 1994)

32. B.V. Shchergin, Near the city of Arkhangelsk, near the ship have (GIZ, Moscow, 1924)

\footnotetext{
${ }^{\mathrm{i}}$ The research is conducted with the financial help of Russian Foundation for Humanities and Government of the Arkhangelsk region «The Russiam North: History, Modernity and Prospects», within research project № 15-14-29002 «a(p)» «Folklore and Speech Practice and Local Identity of the Residents of Arkhangelsk and Severodvinsk».

ii Oral interview with Tikhonova N.V., born in 1962.

iii Oral interview with Rovenko N.V., born in 1958.
} 